\title{
MILITARY EXPENDITURE AND DEBT IN SOUTH AMERICA
}

\author{
J Paul Dunne \\ School of Economics, \\ University of the West of England, Bristol \\ Frenchay Campus, \\ Bristol BS16 1QY \\ and School of Economics, \\ University of Cape Town \\ email: John2.Dunne@uwe.ac.uk
}

Sam Perlo-Freeman

Stockholm International Peace Research Institute

Signalistgatan 9

S-169 70 Solna

Sweden

Email: perlofreeman@sipri.org

\section{Aylin Soydan}

Middlesex University Business School,

The Burroughs,

Hendon

London NW4 4BT

Email: $\underline{\text { A.Soydan@mdx.ac.uk }}$

May 2003

Running Title: South American Milex and Debt

Corresponding Author: J Paul Dunne

*We are grateful to Ron Smith for comments and Dunne is grateful to the ESRC for support under research grant Ref: R00239388.

Correspondence: John2.Dunne@uwe.ac.uk 


\section{MILITARY EXPENDITURE AND DEBT IN SOUTH AMERICA}

The debt crisis that struck South American countries in the 1980s led to severe recession, and chronic economic problems. This paper considers one potentially important contributor to the growth of external debt, namely military spending. It considers the experience of Argentina, Brazil and Chile. It finds was no evidence that military burden had any impact on the evolution of debt in Argentina and Brazil, but some evidence that military burden tended to increase debt in Chile. At the same time Chile was the least affected of the three countries by acute financial crises resulting from the debt problems, although their relative levels of debt were as high or higher. This suggests that military burden may be important in determining debt in countries, but it is only of significance when it is not swamped by other macroeconomic and international factors.

Keywords: Military spending; external debt; South America.

JEL Codes: H56; F40; O54. 


\section{INTRODUCTION}

Military spending is a potentially important determinant of indebtedness for small industrialising and developing economies. While Brzoska (1983) identified the importance of military spending on developing country debt, only a limited literature including Looney $(1987,1989,1998)$ has attempted to investigate this potential effect. More recently Dunne et al (2003) undertook a panel data study of the effect of military expenditure on debt in a sample of small-to-medium-sized industrialising economies. They provide some useful initial findings, but point to the need to better understand the dynamics within the individual countries.

This paper focuses on a particular region, South America, which has suffered badly from external debt crises in recent decades. South American nations borrowed heavily in the seventies and early eighties at a time of easy international credit, with significant amounts of this spent on armaments, building up excessive debt stocks. More recently, heavy borrowing by Argentina during the 'economic miracle' of the 1990s has led to a further debt crisis, with severe knock-on effects for some other countries in the region. The paper considers the relationship between military expenditure, arms imports and debt in Argentina, Brazil and Chile.

The next section looks at the evolution of the debt crisis in South America from its origins in the 1970s, and specifically in the three countries under study. This is followed by a brief discussion of the evolution of military expenditure and arms. The following section discusses the channels through which military expenditure may influence debt, in relation to the issue of internal and external deficits and the methods of financing them. It also considers previous empirical studies. In the next section the model used and the estimation results are presented. The final section provides some conclusions. 


\section{THE DEBT CRISIS IN SOUTH AMERICA}

South America shared with many other countries the damaging impact of the 1974 oil price increase, when the actions of the Organisation of Petroleum Exporting Countries (OPEC) led to a quadrupling of the price of oil. The resulting increase in oil revenues went well beyond the capacity of the OPEC countries to invest productively and were instead deposited in international banks, leading to a massive global surplus of capital. (e.g. Theberge, 1999). Developing countries were seen as valuable potential growth markets and bankers were very keen to lend them this surplus stock of 'petrodollars'. At the same time, most developing countries faced an increased need for credit to pay the greatly increased price of imported oil. In South American countries also sought loans to pursue industrialisation, and, in many cases, to pay for arms imports (Milman, 1998). The oversupply of credit from 'petrodollars' and the accompanying low interest rates made external loans an attractive means of financing current account and public sector deficits ${ }^{1}$. Changes, such as the removal of capital controls, made private sector external borrowing easier and more attractive, as profits from investment could easily be taken out of the country. These private sector debts frequently ended up being nationalised (through bailouts by governments) and became part of public external debt, especially in the case of Chile (Theberge, 1999).

The result of all this was that South American external debt more than quadrupled from just over \$75bn in 1975 to \$314bn in 1983, which was 50\% of regional GDP. Debt service payments rose more than five-fold, from \$12bn in 1975 to \$66bn in 1982. Argentina's debt reached $52 \%$ of GDP in 1982, rising to $85 \%$ by 1989 , Brazil's reached $52 \%$ by 1984 , and Chile's was $123 \%$ in 1982. (World Bank: World Development Indicators)

\footnotetext{
${ }^{1}$ One former Latin American Finance Minister said of the period "I remember how the bankers tried to corner me at conferences to offer me loans. If you are trying to balance your budget, it's terribly tempting to borrow more money instead of raising taxes" (Brandford \& Kucinski, 1988)
} 
A rapid rise in debt in the 1970's had been sustainable, due to low interest rates and appreciating real exchange rates keeping the local currency value of dollar debts manageable (Theberge, 1999). Growth in export earnings, while not as rapid as growth in debt, also helped. In the late seventies and early eighties, however, a number of exogenous changes brought the debt crisis to a head. Firstly, another round of oil price rises in 1978-79 caused problems for oil importing countries, especially Brazil. Secondly, much South American debt was with commercial banks at floating interest rates. When interest rates rose in the US and Europe, as part of monetarist policies aimed at tackling inflation, this led to greatly increased interest payments for debtor nations. Recessions in the developed world that accompanied these policies harmed developing countries' exports, as did falling commodity prices, as many developing countries (including in South America) had a high share of primary commodities in exports. As conditions in South America worsened, capital flight, made easy by financial deregulation, put further pressure on South American finances (Branford \& Kucinski, 1988, Theberge, 1999).

These problems combined to render South American debt service requirements unpayable. Mexico announced in August 1982 that they could no longer maintain debt repayments and as international credit dried up as bankers realised repayments could not be made. South American nations suddenly found themselves facing huge sums of debt principle due for repayment, with no new loans available to refinance them. This provoked a crisis in the international financial system, which it seemed would be crippled by widespread default. By early 1984, however, debt restructuring arrangements had been agreed between most debtor nations and their creditors, through the intervention of the IMF (Theberge, 1999). This preserved the global financial system but placed a heavy burden on debtor economies, as the rescheduling packages typically involved abovemarket interest rates, high commissions, and austerity measures. The IMF forced Governments to cut back public spending to meet debt repayments, even in recessions, and to open their markets to trade and foreign investment (Branford \& Kusinci, 1988).

The breaking of the debt crisis led to severe economic downturns in most countries in the region, with the resulting social unrest contributing to the eventual fall of military 
regimes across the region. Argentina's depression of 1981-82 partly prompted the disastrous Falklands invasion that led to the downfall of the military regime. Chile experienced a particularly severe depression in 1982, with GDP falling by more than $10 \%$. Their monetarist policies and liberalized financial systems had made them a particularly attractive destination for foreign capital in the late seventies, but allowed capital to flee the country equally rapidly when trouble approached. Brazil also suffered a significant recession from 1981-83. Growth across the region remained slow throughout the 80s, with Argentina ending the 'lost decade' for South America with a lower real GDP than at the start ${ }^{2}$.

The rescheduling measures agreed were not enough to make South American debts sustainable, and in 1985 US Treasury Secretary James Baker launched the Baker Plan to provide $\$ 29$ bn of new credit to debtor nations in return for market reforms. This scheme met with little success. Towards the late 1980s, the debt crisis continued and countries such as Argentina and Brazil met with renewed economic turmoil including hyperinflation and recession. Brazil declared a moratorium on their debt repayments in February 1987, though they resumed payments later that year. As a result of this, the international financial system realised that debt reductions were needed to bring the crisis under control. The Brady Plan of $1989^{3}$ provided banks with an opportunity to exchange their debt holdings for 'Brady Bonds'. These were discount bonds, that reduced debt by $65 \%$ but at the cost of high interest rates, or par bonds, which did not reduce debt but had low interest rates, collateralized by US Treasury bonds, or the provision of new lines of credit. (Vásquez, 1996, Branford \& Kucinski, 1988).

Argentina and Brazil signed Brady deals in 1992 while Chile had been using marketbased mechanisms, such as debt-equity swaps (often based on privatizations), to reduce their debt obligations since 1986, and reached further debt-reduction and rescheduling agreements with the banks in 1990, independent of the Brady Plan. Measures such as these enabled most South American countries to bring their debt repayments to

\footnotetext{
${ }^{2}$ Stiglitz (2002) provides a critical appraisal of the role of the IMF.

${ }^{3}$ Named after new US Treasury Secretary Nicholas Brady
} 
manageable levels, and allowed their economies to grow strongly through the 1990s. However, debt levels continued to grow as new borrowing became easier, and repayments continued to exact a heavy burden on public service provision. Economic growth was accompanied by high levels of unemployment and growing inequality. (Labán \& Larraín, 1998).

In Argentina, the seeds of future problems were being sown. The incoming Menem government tackled hyperinflation in 1990 by pegging the peso to the dollar and establishing a Currency Board which was to ensure convertibility, by maintaining international reserves at least as great as the narrow money supply. This established monetary stability, but led to an overvalued exchange rate which made Argentine exports uncompetitive, especially after the 'Tequila crisis' in Mexico in 1994-95 put pressure on the currency regime. While inward investment was attractive, so was repatriation of profits and the tight monetary regime squeezed domestic industry. Despite the growth in real GDP, unemployment rose rapidly in the first half of the decade, and remained persistently high. When economic growth ground to a halt after 1999, it became increasingly difficult to maintain debt repayments (Perry \& Servén, 2002). A severe loss of liquidity plunged the country into economic crisis in 2001, with a sharp economic contraction and multiple defaults on overseas debt in 2002. Brazil, partly influenced by 'contagion' from the Argentine crisis, has also come close to default, but has obtained new financing from the IMF in $2002^{4}$.

Figures 1 to 4 below show the evolution of debt in Argentina, Brazil and Chile in levels and as a share of GDP between 1970 and 2000. We see in each case debt rising rapidly between around the mid-70s and the early 80 s, the period of easy 'petrodollar' credit, then again from the early-to-mid 1990s, a time of strong economic growth when the debt crisis was widely seen as having been dealt with. During the crisis period of the $80 \mathrm{~s}$, debt rose only slowly, as although interest on existing debt was very high, new borrowing was next to impossible in most cases.

\footnotetext{
${ }^{4}$ Recent news reports on Argentina and Brazil, e.g. from BBC News online, http://news.bbc.co.uk.
} 


\section{<Figures 1-4 here>}

This suggests we can divide the evolution of debt into a number of phases. First, the build-up of debt from 1974. Second, growing economic problems from 1979, leading to the debt crisis coming to a head in 1982. Third, continuing crisis amidst partial and temporary solutions based around rescheduling until 1989 when the Brady debt reduction scheme was launched. Fourth, from 1992-1993 onwards, when the Brady scheme and other measures had enabled South American countries to manage their debt, a renewed debt build-up. This continued to the end of the period under study.

\section{MILITARY EXPENDITURE AND ARMS IMPORTS IN ARGENTINA BRAZIL AND CHILE}

Clearly the South American debt crisis of the 1980s had a number of underlying causes, such as the easy availability of credit in the 1970s, the fall in commodity prices, recession in the developed world and the sharp rises in interest rates in the late seventies/early eighties. Another potentially important contributing factor for the build up of debt within the region is the degree of military spending, particularly when military expenditure is used to import weapons systems from abroad.

In attempting to analyse the effect of military expenditure on debt in South America a major problem is the inconsistent nature of the data. Governments have frequently hidden military expenditure in other budget lines, and as militaries have often had access to additional, non-transparent sources of funding such as military-run industries. The main providers of international military expenditure information are the Stockholm International Peace Research Institute (SIPRI) and the US Arms Control and Disarmament Agency (ACDA), now merged into the State Department. However in each case, data series presented in different editions of the organisations' yearbooks are not inter-consistent, as they are frequently subject to re-estimation. SIPRI now maintains consistent series back to 1988 . 
The military expenditure series used in this study were constructed by Perlo-Freeman (2002) based on an analysis of different sources of data in the SIPRI archives. The series for Argentina is based on that constructed by Thomas Scheetz (Scheetz, unpublished data series), based on a close analysis of the Argentine budget. Data for Chile is based on a similar series from Scheetz up to 1991, and IMF Staff Country reports thereafter, which include a number of items such as military pensions and proceeds from copper exports used to finance arms imports, that are not in the official Chilean defence budget. Data for Brazil combines a series constructed by Ball (1984) up to 1980, data from the IMF's Government Financial Statistics up to 1991, and responses to SIPRI military expenditure questionnaires thereafter.

SIPRI do provide consistent data series for major conventional arms imports back as far as 1970, though these require careful interpretation, as they are not monetary figures but trend-indicators, giving an indication of the value of weapons systems, rather than the price which can be highly variable for the same weapon, depending on a variety of political and short-term market factors. For example, weapons given away free as military aid would obviously create no economic burden on the recipient, but would appear in the SIPRI series as if they had been sold at full price.

Figures 5-8 below plot the military expenditure and arms imports of Argentina, Brazil and Chile at 1995 prices. Argentine military expenditure rises sharply through the late 1970s, remaining high in the early 1980s, then falling away rapidly after 1983, coinciding with the restoration of democracy, the impact of the debt crisis, and a 1984 peace treaty with Chile. It levels off after a further sharp fall in 1990. In Brazil, military expenditure falls gradually up to the mid-1980s, then rises thereafter. Perhaps somewhat surprisingly, the turning point coincides roughly with the restoration of democracy in 1984. Chilean military spending rises sharply through the mid to late 1970s and early 1980s, thereafter at a slower rate. Turning to arms imports, the patterns for Argentina and Brazil are similar to those for military expenditure, only more erratic or 'lumpy', due to the uneven nature of arms deliveries. Argentine imports are particularly high in 1983-84, when the 
country was rearming and replacing lost equipment in the wake of the Falklands/Malvinas war of 1982. Chilean arms imports, however, follow a cyclical pattern with no discernible connection to military expenditure. Indeed, Perlo-Freeman (2002) finds a very close cointegrating relationship between military expenditure and arms imports in Argentina and Brazil, but no correlation between the two variables in any form for Chile. This may be due to the way Chilean arms imports are financed, which is largely through a levy on the proceeds of Chilean copper exports. The Chilean armed forces also borrow ahead against future copper proceeds, so that they are largely immune to changes in the defence budget (Scheetz, 1996).

High levels of arms imports in Argentina and Brazil in the late 1970s, and rising military spending in Argentina and Chile during the same period does suggest that they contributed to the growth of debt in these countries in the lead up to the 1980 s crisis. The growth of Argentine debt in the 1990s, however, came at a time of low military expenditure and virtually zero arms imports. Perlo-Freeman (2002) found Argentine military spending to depend positively on GDP and Chilean military spending and negatively on debt and accelerating inflation. The transition to democracy was found to have a significant negative effect on military spending only during the Menem era (from 1990), while the post-Falklands war re-armament of 1983 had a significant positive effect. Brazilian military spending appeared to be subject to a rising trend and otherwise to depend only on debt and inflation (negatively in each case). Chile was similar, except that there was a clear negative impact of the degree of democracy on military spending, and some evidence of a positive effect of the changing level of tension with Argentina, though Argentine military spending itself was insignificant.

It is interesting that debt, along with inflation, was a common factor to all three countries, with the empirical results suggesting that high levels of indebtedness may restrict access to the credit often needed for arms sales, or may divert government expenditure that might have been for the military into servicing debt. This suggests that there is some relation between military expenditure and debt. 


\section{Figures 5-7 here}

\section{PUBLIC DEFICITS, DEBT AND MILITARY EXENDITURE}

Most analyses of the economic effects of military expenditure, positive and negative, relate to the effect of military expenditure on growth. The results present a very mixed picture, although most studies tend to show an insignificant or negative impact (Dunne, 1996). Analysis of the effect of military expenditure on external debt is more limited. However, some authors, starting with Brzoska (1983) have pointed to military expenditure as being an important variable in explaining the rise of foreign debt in a number of developing countries, suggesting that this has led to reduced economic growth.

The relationship between military expenditures and external debt can be of two forms. In general, as a budget item, military expenditure creates the need for funding. If a rise in military expenditure, say, cannot be financed through taxation, it will create a deficit. As discussed in Dunne et al (2003), this may be financed in four different ways: printing money, using foreign exchange reserves, borrowing abroad and borrowing domestically. Each of these methods has some limits and implications, which are widely discussed in the literature. Although there are links between the implications of methods used, as a first approximation, the methods of deficit financing are associated with different macroeconomic imbalances: money printing with inflation; foreign reserve use with the onset of exchange crises; foreign borrowing with an external debt crisis (Fischer and Easterly, 1990).

High public sector deficits relative to GDP therefore potentially create a need for foreign borrowing and external debt accumulation, particularly when the means to finance deficits domestically is limited. Hence, there is likely to be a relatively close relation between the deficits and foreign borrowing in developing countries, where tax revenues are already limited to finance public expenditures, money creation is already (mis)used at high levels, financial markets are relatively thin and domestic borrowing possibilities are limited compared to the richer economies. As Fry (1997) observes, the typical OECD 
country finances about 50 percent of its deficit from voluntarily domestic sources, while the same ratio for a typical developing country is only about 8 percent. We have also seen that in the 1970s, the very easy availability of credit and low international interest rates faced by South American nations made this a highly attractive way to finance deficits.

More directly, a component of military spending will be allocated to pay for arms imports, which will create a need for foreign exchange. If the economy lacks foreign exchange, it will need to obtain it from external sources, usually by borrowing. It is also possible that depreciations in currency lead to increasing foreign exchange requirements from those expected over the life of a project ${ }^{5}$. Again in the 1970s, external borrowing was often a preferred means of financing balance of payments deficits for South American countries. Furthermore, far from using up foreign reserves to pay for overseas purchases, Argentina, Brazil and Chile all saw their reserves increase over the second half of the 1970s, at the same time as they were building up their debts.

The key question in analysing the effect of military expenditure on debt then, is how such expenditure is financed; if through higher tax revenues or lower government spending in other areas, it will not create a deficit; if higher military spending does create a deficit, this may or may not be financed through external debt. In the case of arms imports, the key question is whether they can be funded through export earnings or existing reserves, or whether they require new credit. Overall, there are reasons to suppose that military expenditure and arms purchases may have contributed to the build-up of debt in the three countries under study, especially in the 1970s.

Turning to previous empirical work on the relationship between military expenditure and debt. Looney and Frederiksen (1986) follow Brzoska (1983) in suggesting that the impact of high external borrowing due to defence on a country's overall growth performance and resource allocation depends on the countries capacity of international borrowing. Looney and Frederiksen (1986) and Looney (1989) allocate developing countries to these groups based on their capability to raise external debt, using factor analysis and discriminant

\footnotetext{
${ }^{5}$ This happened in a recent South African arms deal, as discussed in Dunne (2003).
} 
analysis. They suggest that unconstrained countries will be able to support higher level of arms imports. Looney $(1989,1998)$ then drew attention to the weakness of the literature on the motives of debt accumulation and indicated the significance of military expenditures, specifically arms imports, for the Third World indebtedness. In his empirical analysis Looney (1989), developed three models, for ME (Military Expenditure), PDB (Public External Debt), AI (Arms Import) and ran regressions for whole sample, resource-constrained countries and unconstrained countries using two stage least squares.

In a more recent contribution Gunluk-Senesen and Sezgin (2002) considered the relation between military debt and arms exports in Turkey. As direct data are not available on cash payments for arms imports and military debt, they resorted to an indirect analysis and consider the likely impact of defence on external indebtedness via a model of debt and arms imports (in fact arms transfers to Turkey). To do this they estimated a model where the growth of external debt was a function of the growth of real GNP, merchandise imports, merchandise exports, real defence expenditures, real defence equipment expenditures and real arms imports. They found that arms imports to be the only significant defence related variable, though not strongly significant.

Dunne et al (2003) use panel data techniques to explore the effect of military expenditure on debt on a sample of industrialising economies around the world between 1960 and 2000. Their model estimates the share of external debt in GDP as a function of GDP growth, exports as a share of GDP, international reserves as a share of GDP, and military expenditure as a share of GDP (military burden). GDP growth, exports and reserves are included as they may measure the ability of the economy to finance military expenditure and arms imports without resorting to borrowing. In a static panel data model, they find military burden to have a positive but insignificant effect on the debt burden, while GDP growth and reserves have a significant negative effect, and exports a significant positive effect. However, when a dynamic model is used on the first differences, of all the variables, with Arellano-Bond (1991) GMM estimators, a significant positive effect of 
military burden is found. GDP growth is still significant and negative, indicating that a strong economy makes it easier to manage debt, while the export and reserve variables become insignificant. The lagged dependant variable is very strongly significant and positive.

\section{MODELLING MILITARY EXPENDITURE AND DEBT}

In developing a model of military spending and debt, the aim is not to provide a complete explanation of the evolution of debt, but to discern the specific effects of military expenditure and arms imports on debt, given the capacity of the economy to finance the domestic and foreign spending that military expenditure involves. To this end, along with military expenditure or arms imports, the estimated model includes GDP, level and growth and exports and foreign exchange reserves as possible determinants. In addition, the 6-month London Interbank Offer interest rate (LIBOR) on dollar deposits is included, as the interest rate paid on much South American debt was tied to the LIBOR .

In some cases, the expected sign of the independent variables is not clear. High interest rates will mean higher interest payments added to the debt, but will also discourage new borrowing. Rising GDP automatically lowers the debt burden as a share of GDP, but may also encourage new borrowing. High reserves may indicate an enhanced ability to manage debt; also, new debt was sometimes used to build up reserves, as discussed, so this variable can probably be expected to have a positive sign, if it is significant. Export earnings help generate foreign currency to make debt payments, and also allow imports to be made without resorting to overseas borrowing, so this variable should have a negative sign. Finally, we expect military spending and/or arms imports to be contributing factors to debt, and so to have a positive sign, if they are significant.

To deal with the question of how to compare nominal values of debt and other variables across time, debt, military expenditure, exports and reserves are taken as shares of GDP. (With dollar values converted to local currency at official exchange rates). It does not

\footnotetext{
${ }^{6}$ As a mark up over the LIBOR rate
} 
make sense to express arms imports as a share of GDP, however, since the SIPRI series for arms imports used is not a monetary measure. The dependent variable is the debt burden, with a lagged debt burden and the current and lagged value of each independent variable included initially and a general-to-specific approach to estimation is adopted. Current and lagged GDP are entered in log form and given the likely close relationship between military spending and arms imports, they are not included at the same time. Thus two equations are estimated, one with military burden (current and lagged) as independent variables, the other with arms imports.

The equation to be estimated for each country is therefore:

$(\text { Debt/GDP })_{t}=a_{0}+a_{1}(\text { Debt/GDP })_{t-1}+a_{2}(\log \text { GDP })_{t}+a_{3}(\log \text { GDP })_{t-1}+a_{4}(\text { Exports/GDP })_{t}+$ $\mathrm{a}_{5}(\text { Exports/GDP })_{\mathrm{t}-1}+\mathrm{a}_{6}(\text { Reserves/GDP })_{\mathrm{t}}+\mathrm{a}_{7}(\text { Reserves/GDP })_{\mathrm{t}-1}+\mathrm{a}_{8}(\text { Milex/GDP })_{\mathrm{t}}$ $+\mathrm{a}_{9}(\text { Milex/GDP })_{\mathrm{t}-1}+\mathrm{a}_{10}(\text { LIBOR })_{\mathrm{t}}+\mathrm{a}_{11}(\text { LIBOR })_{\mathrm{t}-1}$.

With arms imports replacing military burden when its impact is considered.

\section{RESULTS}

Data for debt, GDP, exports and foreign exchange reserves are taken from the World Bank World Development Indicators. Data for military expenditure uses the series described in section 3, and data for arms imports are the SIPRI trend indicators. Data for the LIBOR is taken from various editions of the IMF International Financial Statistics. The data is for 1970-2000 for Argentina and Chile, but for 1971-2000 for Argentina, as the military spending data used did not have data for 1970 .

Estimating a first order autoregressive distributed lag model (ARDL), with Microfit 4.1, gave the results in Table 1

<Table 1 here> 
For Argentina, a joint variable deletion test on the lags of the independent variables was not rejected. When these were removed, LGDPR, RESSH and MB were still insignificant. Adding, LGDPR and RESSH to the joint deletion test failed to reject the null, with $F(7,18)=0.88$, giving the following results:

$$
\begin{aligned}
\mathrm{DB} & =-0.12+0.49 \mathrm{DB}(-1)+2.79 \mathrm{EXSH}-7.84 \mathrm{MB}+0.16 \mathrm{LIBOR} \\
(-0.07)(1.9) & (1.8) \\
\mathrm{Rsq} & =0.63
\end{aligned}
$$

There was some evidence of heteroscedasticity, so $t$ ratios based upon the heteroscedastic robust standard errors are presented. Problems of serial correlation and normality that had been apparent in the general model were not present in this model.

For Brazil, a joint variable deletion test on the insignificant variables: LGDPR, LGDPR(-1), RESSH, RESSH(-1), MB and MB (-1) was not rejected, with $\mathrm{F}(6,17)=0.55$, while a test of the coefficients on LIBOR and its lag being of equal and opposite sign was also accepted. Diagnostic tests did not suggested any problems with this specification:

$$
\begin{aligned}
& \mathrm{DB}=0.10+0.94 \mathrm{DB}(-1)+1.89 \mathrm{EXSH}(-1)-2.95 \mathrm{EXSH}(-1)-0.01 ? \mathrm{LIBOR} \\
& \text { (3.0) (6.1) (4.4) (-2.9) } \\
& \text { Rsq }=0.63
\end{aligned}
$$

For Chile there were some problems with normality, so care is needed with the interpretation of tests of significance. A joint variable deletion test on the most insignificant variables, LGDPR, EXSH and MB(-1), was clearly not rejected, with $\mathrm{F}(3,18)=0.22$. However, the coefficients of RESSH and RESSH(-1), as well as the coefficients of LIBOR and LIBOR(-1), are close to being equal and opposite. A Wald test fails to reject these restrictions. Using ? CRESSH and ? LIBOR gave:

$$
\begin{aligned}
\mathrm{DB}= & -5.52+0.85 \mathrm{DB}(-1)+0.33 \mathrm{LGDPR}(-1)-0.99 \mathrm{EXSH}(-1) \\
& (4.7) \quad(11.7) \\
& +1.40 ? \mathrm{RESH}+ \\
& (2.1) \\
\text { Rsq } & =0.67 \mathrm{MB}-0.03 ? \text { LIBOR }
\end{aligned}
$$


This leaves us with a model that suggests that military burden has a clear and significant positive impact on debt for Chile. It is the only country for which this results holds. It is also the country that has seen the least economic turmoil in recent years. This does suggest that military burden may be important in determining debt in countries such as Chile, but it is only of significance when it is not swamped by other macroeconomic and international factors.

As an alternative to using military burden, the same models were estimated using current and lagged arms imports instead as independent variables. The results of the general dynamic model are shown in Table 2 below. The variable AIMP is the SIPRI figure for arms imports in millions of 1995 US\$ (representing nominal rather than actual monetary value).

In the case of Argentina, the diagnostics tests suggested problems of serial correlation, non-normality of residuals and heteroscedasticity, which remained and even worsened after the removal of insignificant variables. An examination of the residuals suggested the problem was caused by extreme values in the years 1989 and 1990. This implies that there were specific factors in these years not accounted for by the model. Introducing dummy variables for these years removed the diagnostic problems.

The removal of the most insignificant variables, EXSH and EXSH(-1), left LGDPR and LIBOR clearly insignificant, but the RESSH variables close to significant. The joint deletion of EXSH, EXSH(-1), LGDPR and LIBOR was clearly accepted, whereupon the restriction of equal and opposite coefficients on current and lagged RESSH, and on current and lagged AIMP, was also accepted. This led to the following results:

$$
\begin{aligned}
& \mathrm{ADB}=-3.96+0.79 \mathrm{ADB}(-1)+0.32 \mathrm{LGDPR}(-1)+1.74 \mathrm{DRESSH}-0.00011 \mathrm{DAIMP}+ \\
& (-5.4) \quad(12.1) \\
& 0.018 \mathrm{LIBOR}(-1)+0.43 \mathrm{DUMMY} 1989-0.30 \mathrm{DUMMY} 1990 \\
& \quad(5.6) \\
& \mathrm{R}^{2}=0.95
\end{aligned}
$$


These results indicate a significant negative impact of the change in arms imports on changes in the debt burden, not the result we were expecting.

In the case of Brazil the arms imports variables were insignificant, which means we are left with the same model as before, as both the military burden variables were also insignificant. There is no evidence that military expenditure, or arms imports have had any effect on debt in Argentina. For Chile, the arms import variables were again insignificant (and ended up being removed in the final model), but the earlier model found a clear positive effect of military burden on debt. This suggests that this effect has to be explained in ways other than the Government spending money on expensive arms imports. It is important to mention the caveat that arms imports data are difficult to collect and the figure used here may not reflect all arms flows. Nevertheless, the differences across these countries are interesting.

\section{CONCLUSIONS}

The debt crisis that struck South American countries in the 1980s followed a typical pattern. Countries borrowed heavily during conditions of easy international credit and relatively strong domestic economies. Then a change for the worse in both domestic and especially international circumstances led to a situation in which the debtor countries could not service their debts, leading to loss of international credit-worthiness, severe recession, and crippling debt service payments, even when restructuring agreements were reached.

One potentially important contributor to the growth of external debt was military spending and the focus of this study was to empirically evaluate the effect of military spending on debt in three South American countries: Argentina, Brazil and Chile. Despite some clear similarities in the experiences of the countries there are also some clear differences. There was no evidence that military burden had any impact on the evolution of debt in Argentina and Brazil, but there was some evidence that military burden tended 
to increase debt in Chile. Indeed, it was only in the case of Chile that a meaningful relationship emerged with the various economic variables used in general. This is in contrast to Dunne et al (2003), where a panel data study of a larger sample of countries was able to draw meaningful conclusions. At the same time Chile was the least affected of the three countries by acute financial crises resulting from the debt problems, although their relative levels of debt were as high or higher. This does suggest that military burden may be important in determining debt in countries, but it is only of significance when it is not swamped by other macroeconomic and international factors. 


\section{References:}

Arellano M. and Bond S. (1991) Some tests of specification for panel data models: Monte Carlo evidence and an application to employment equations. Review of Economic

Studies, 58 (2), 277-297.

Ball, N. (1984): Third World Security Expenditure: A Statistical Compendium, FOA Report, Stockholm.

Branford, S. and Kucinski, B (1988) The Debt Squads. London/New Jersey: Zed Books.

Brzoska, M. (1983) "Research Communication: The Military Related External Debt of Third World Countries", Journal of Peace Research, 20, 3, 271-277.

Dunne J. P. (2003) "The Making of Arms in South Africa", Economists Allied for Arms Reduction (ECAAR) Review, 1, January 2003.

Dunne, P; Perlo-Freeman S. and Soydan, A. (2003)"Military Expenditure and Debt in Small Industrialised Economies: A Panel Analysis". Defence and Peace Economics. This issue.

Dunne, P (1996)"Economic Effects of Miltary Spending in LDCs: A Survey", Chapter 23 in Gleditsch, NP, Cappelen, A, Bjerkholt, O, Smith, R and Dunne, P (eds) (1996) The Peace Dividend, Contributions to Economic Analysis Series. North Holland, pp 439-464.

Fischer, S and Easterly, W (1990). "The Economics of the Government Budget Constraint", The World Bank Research Observer, Vol.5, No.2, pp.127-142.

Fry, M. J. (1997). Emancipating the Banking System and Developing Markets for Government Debt. London, New York: Routledge.

Gunluk-Senesen, G and Sezgin, S (2002). Turkey's defence expenditures and debt burden". Paper presented at the $6^{\text {th }}$ Middlesex Conference on Economics and Security, June 2002, London.

Labán, R.M. and Larraín , F.B (1998): “The Return of Private Capital to Chile in the 1990s: Causes, Effects, and Policy Reactions", Harvard Institute for International Development, Development Discussion Papers, no. 627, March 1998.

Looney, R. E. (1987) Impact of military expenditure on Third World debt. Canadian Journal of Economics, 8, 1, 7-26.

Looney, R. E. (1989) The influence of arms imports on Third World debt. Journal of Developing Areas, 23, 2, 221-31. 
Looney, R. E. (1998) Foreign capital flows and defense expenditures: Patterns of causation and constraint in Pakistan. Canadian Journal of Development Studies, 19, 1, 117-132.

Looney R. E. and Frederiksen P. C. (1986) Defence expenditure, external public debt and growth in developing countries. Journal of Peace Research, 23, 4, 329-38.

Milman, CD (1998) “The Latin American Foreign Debt Revisited", Global Finance Journal, 9(2), pp.173-180.

Perlo-Freeman, S. (2002) The Demand for Military Spending in Developing Countries, Unpublished PhD Thesis, Middlesex University Business School, London.

Perry, G. and Servén, L: "The Anatomy of a Multiple Crisis: Why Was Argentina Special and What Can We Learn From It", Paper prepared for National Bureau of Economic Research Project on Exchange Rate Crises in Emerging Markets, Session on Argentina, July 17, 2002.

Scheetz, T. S. (1996): "The 'Peace Dividend' in Argentina and Chile: An evaluation of opportunities for defense conversion", paper commissioned by Bonn International Centre for Conversion for its Conversion Survey, mimeo Universidad Nacional de Quilmes, Argentina.

Scheetz, T.S., unpublished data series, mimeo Universidad Nacional de Quilmes, Argentina.

Stiglitz, J.E. (2002) Globalization and Its Discontents. W.W. Norton and Company.

Theberge, A. (1999) "The Latin American Debt Crisis and its Historical Precursors", Seminar paper, Columbia State University, available at URL http://www.columbia.edu/ ad245/theberge.pdf.

Vásquez, I. (1996) "The Brady Plan and Market-Based Solutions to Debt Crises", The Cato Journal, Vol. 16, No.2, Fall 1996. 
Table 1: Estimation Results: General Dynamic Model

\begin{tabular}{lcrrrrr} 
& Argentina & \multicolumn{2}{c}{ Brazil } & \multicolumn{2}{l}{ Chile } \\
Regressor & Coefficient T-Ratio & \multicolumn{2}{c}{ Coefficient T Ratio } & \multicolumn{2}{c}{ Coefficient T-ratio } \\
C & -0.648 & -0.1 & 0.090 & 0.1 & -4.534 & -1.6 \\
DB(-1) & 0.523 & 2.7 & 1.000 & 4.7 & 0.830 & 8.2 \\
LGDPR & -0.479 & -0.7 & -0.245 & -0.8 & -0.214 & -0.4 \\
LGDPR(-1) & 0.533 & 0.8 & 0.243 & 0.9 & 0.482 & 1.0 \\
EXSH & 2.918 & 1.6 & 1.606 & 2.2 & 0.055 & 0.1 \\
EXSH(-1) & -1.445 & -0.8 & -2.744 & -3.9 & -1.029 & -1.5 \\
RESSH & -0.512 & -0.2 & 0.788 & 1.2 & 1.328 & 1.5 \\
RESSH(-1) & 1.570 & 0.6 & 0.144 & 0.2 & -1.014 & -1.0 \\
MB & -3.286 & -0.5 & -3.606 & -1 & 7.415 & 2.7 \\
MB(-1) & -1.520 & -0.2 & 1.656 & 0.5 & 1.015 & 0.4 \\
LIBOR & -0.007 & -0.4 & -0.009 & -2.5 & -0.026 & -2.5 \\
LIBOR(-1) & 0.020 & 1.5 & 0.013 & 2.8 & 0.026 & 2.4 \\
& & & & & & \\
rsq & 0.723 & & 0.921 & & 0.681 & \\
ser & 0.117 & & 0.034 & & 0.032 & \\
N & 29 & & 29 & & 30 &
\end{tabular}

With:

Dependent variable: ADB: Debt/GDP

LGDPR: $\log$ real GDP

EXSH: Exports/GDP

RESSH: Foreign Exchange reserves/GDP

MB: Military spending/GDP

LIBOR: London Interbank Offer Rate, 6 months, dollar deposits. 
Table 2: Estimation results of general dynamic model with arms imports

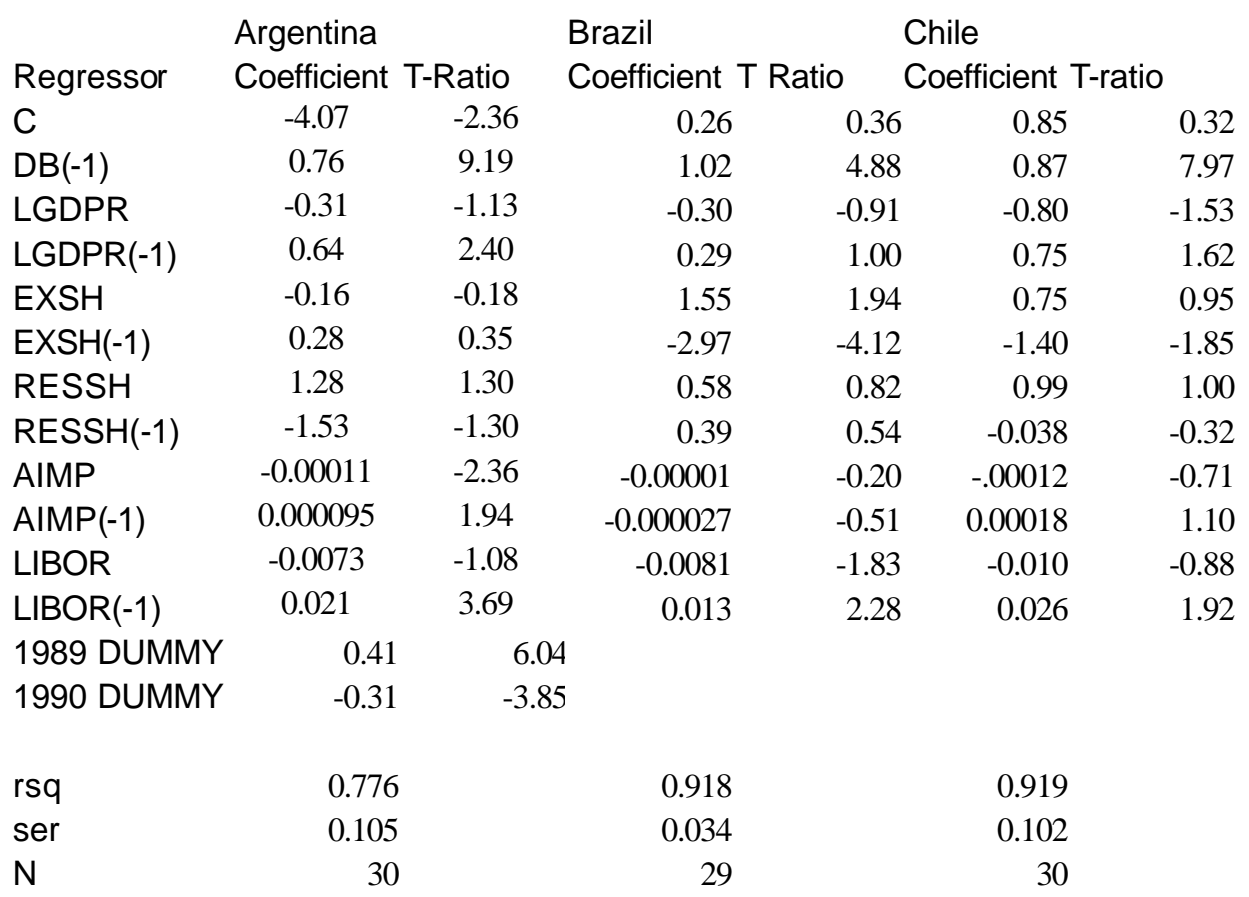


Figure 1

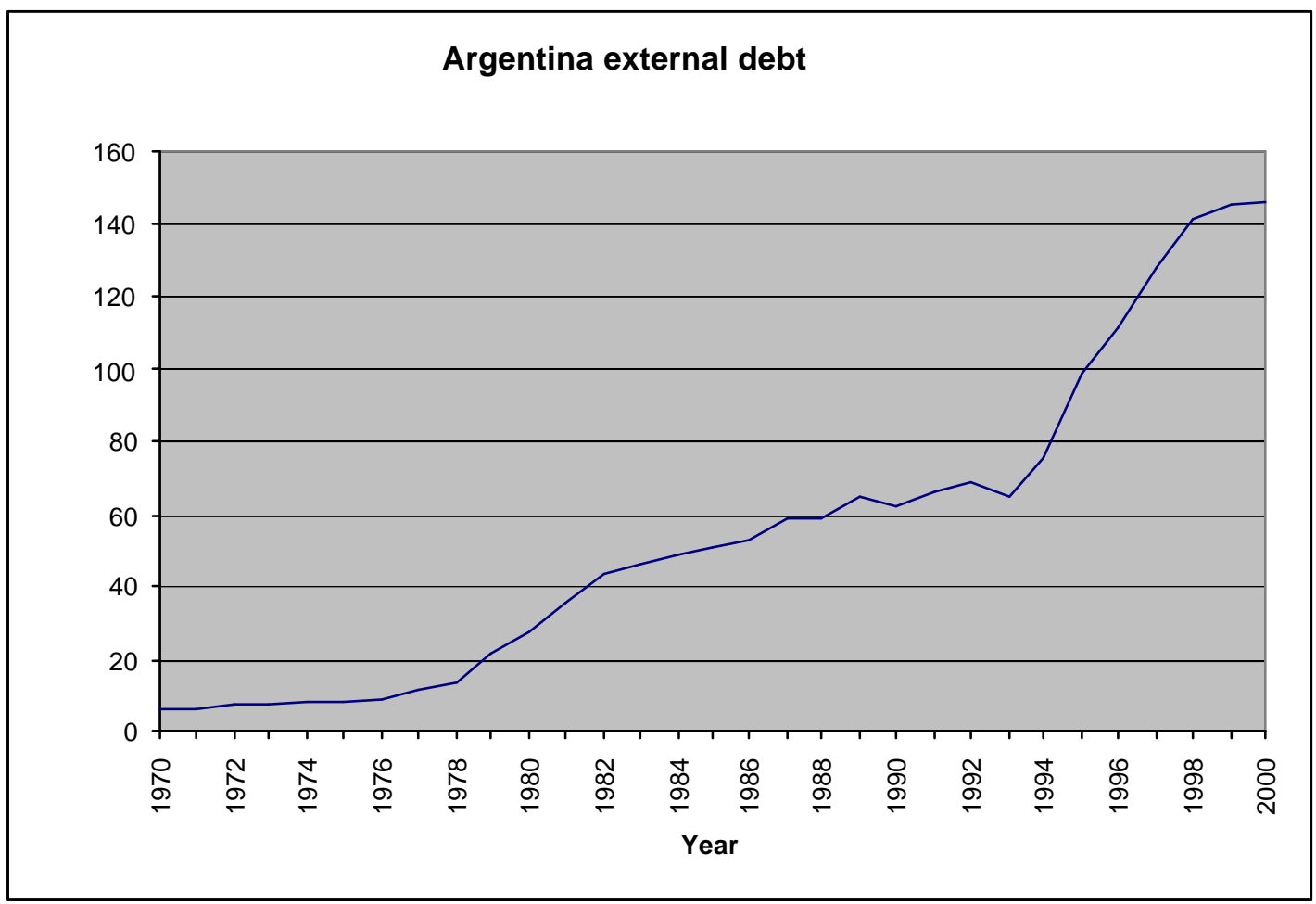


Figure 2

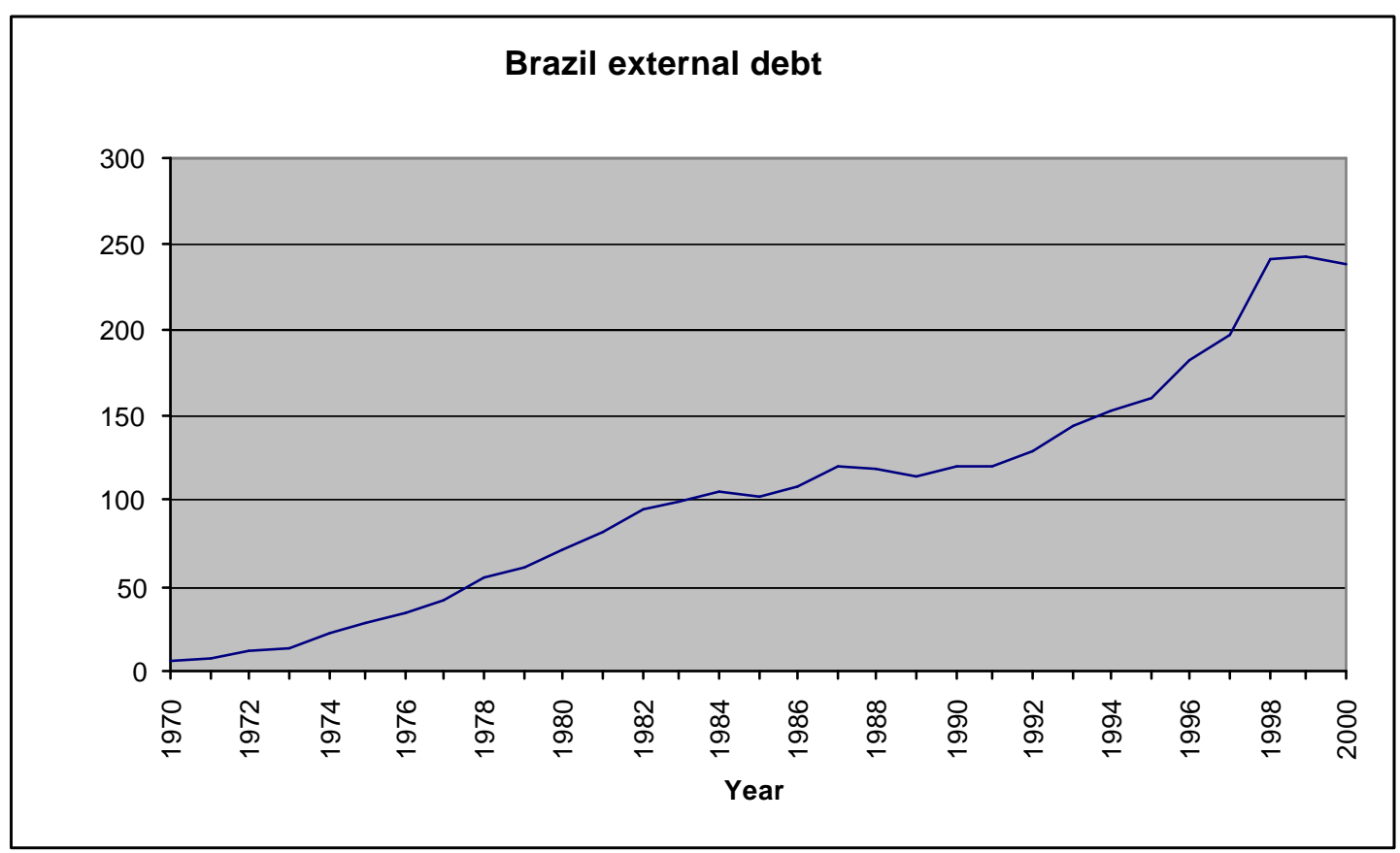


Figure 3

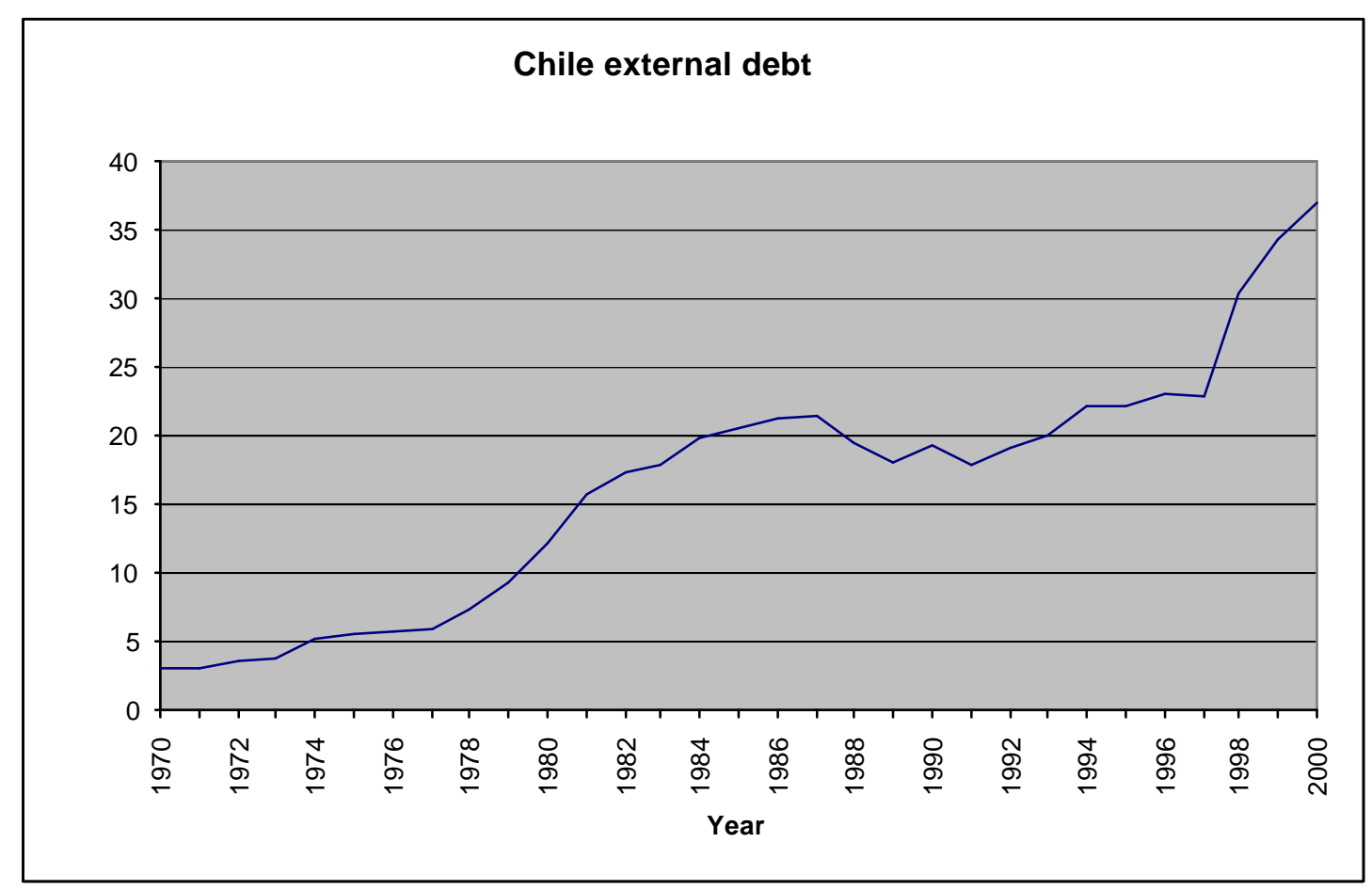


Figure 4

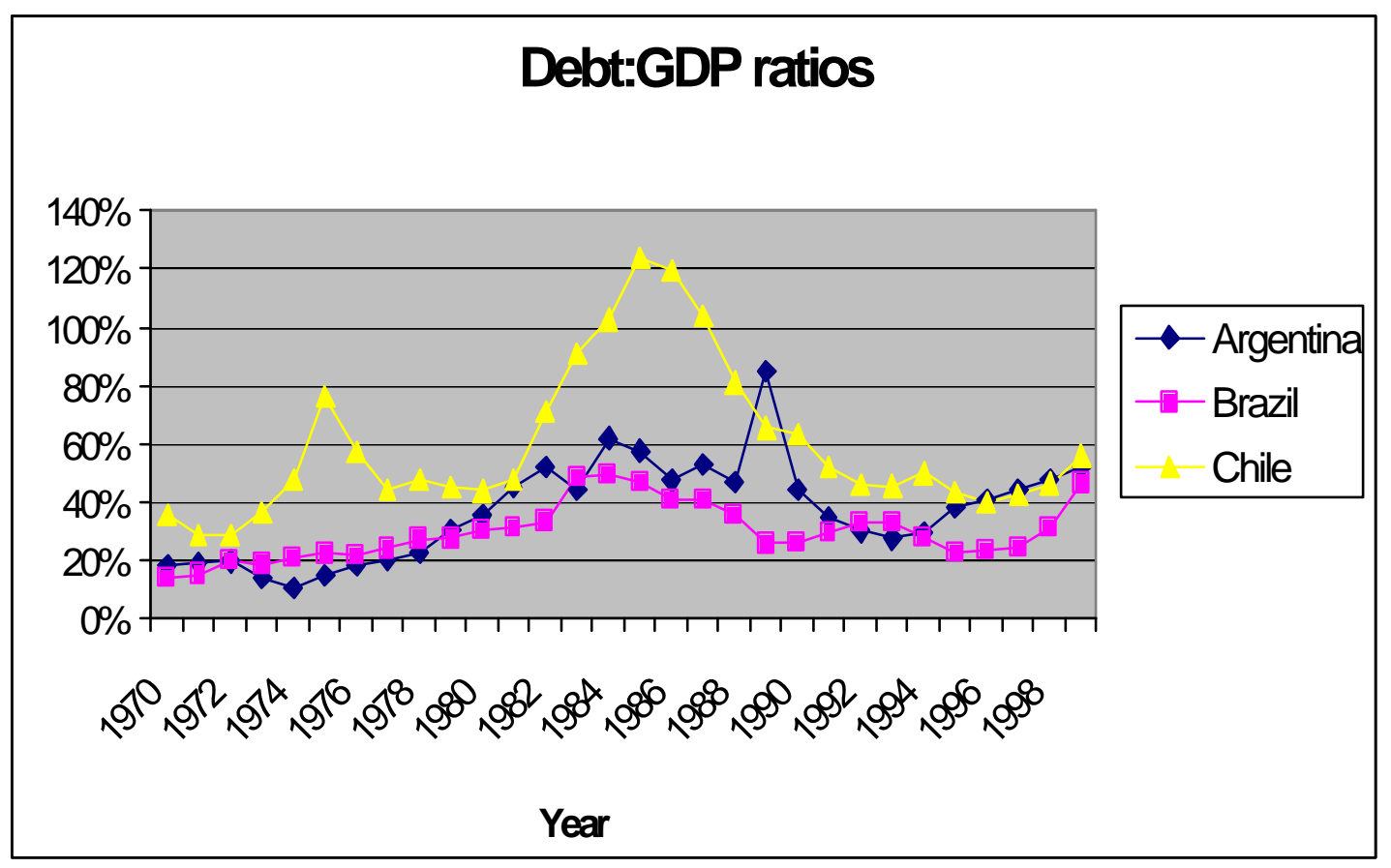


Figure 5

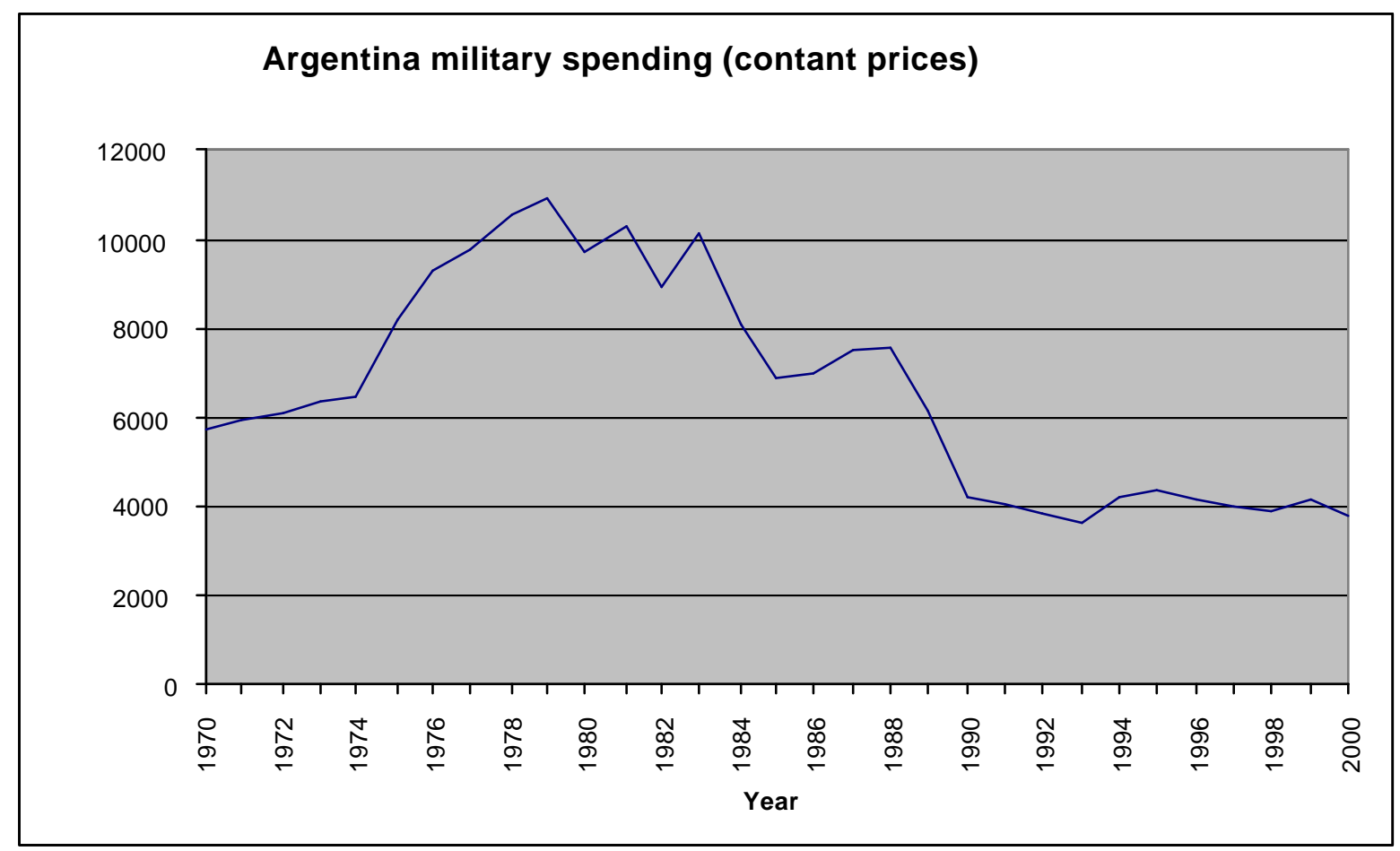


Figure 6

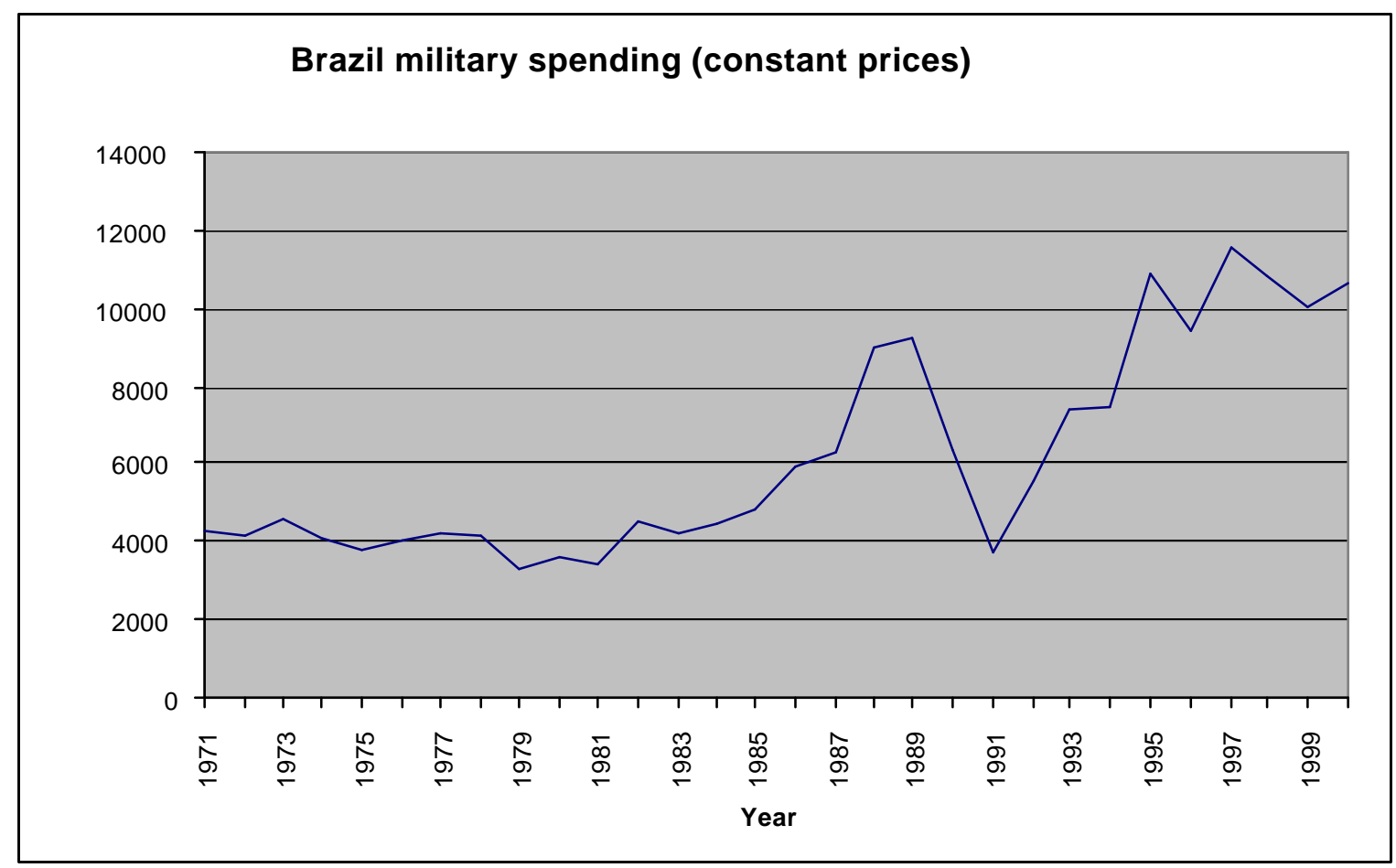


Figure 7

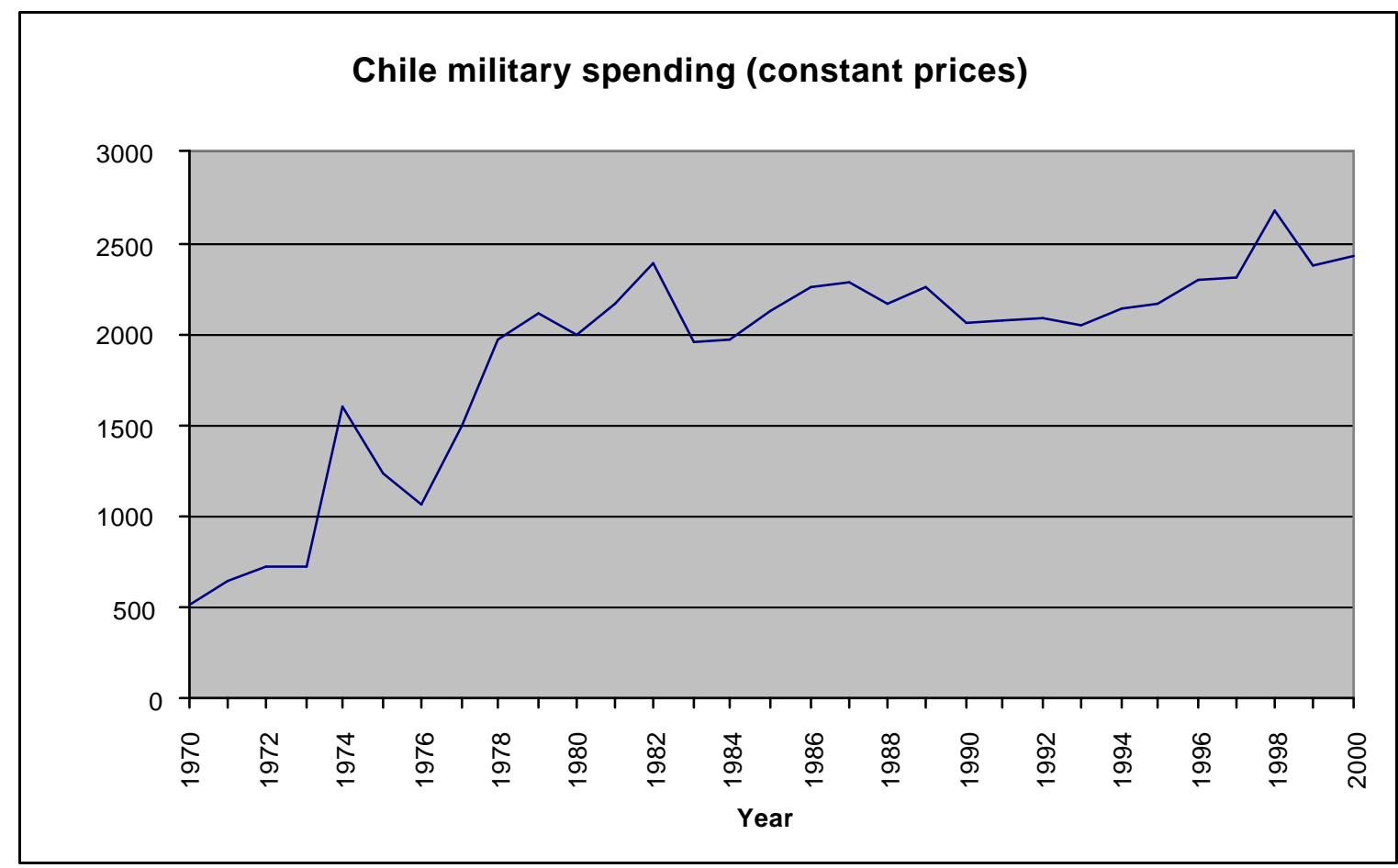


Figure 8

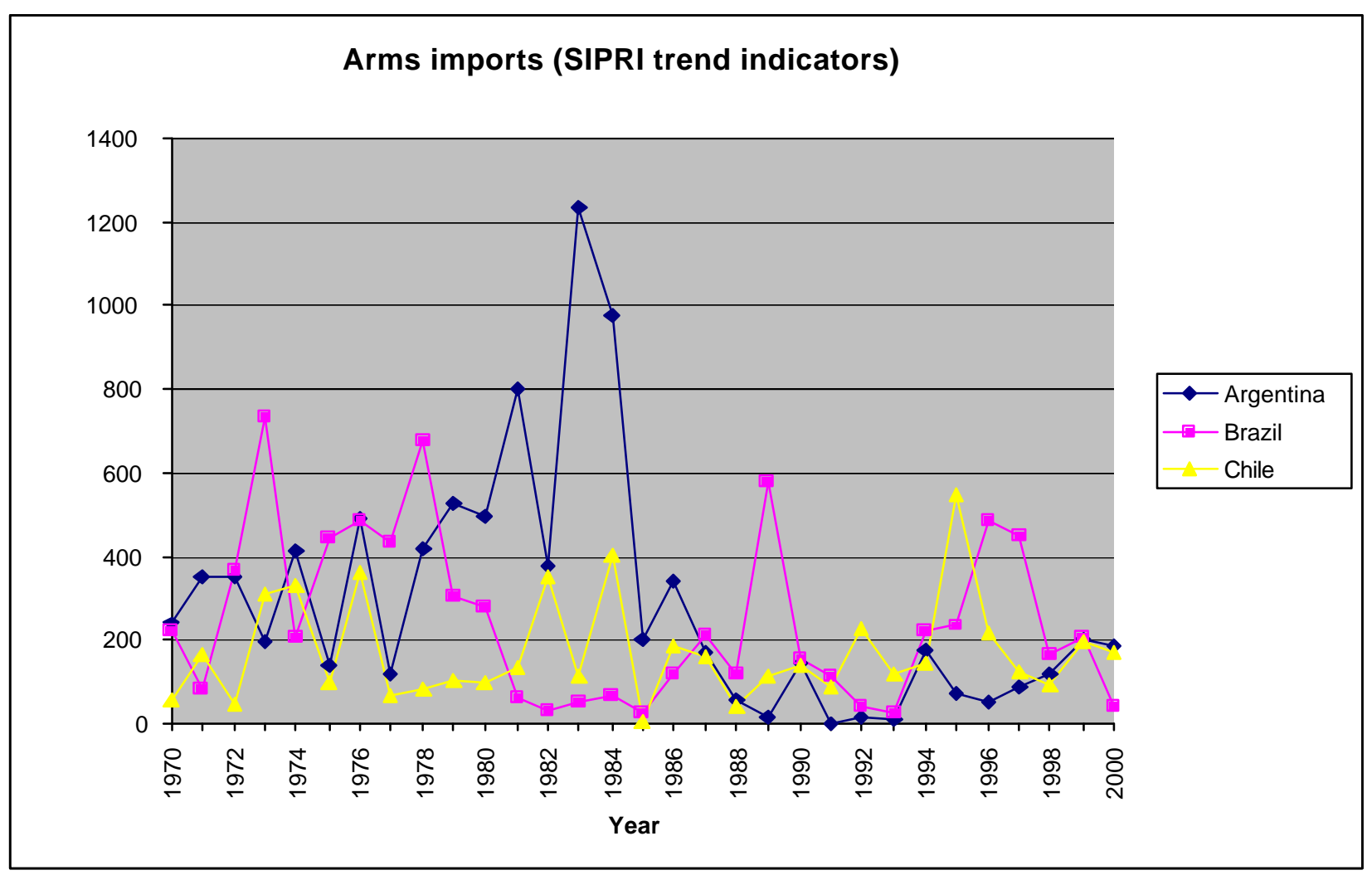

